\title{
УДК [373.3:004]:81
}

\section{ЕТАПИ ВПРОВАДЖЕННЯ ІКТ В ОСВІТНІЙ ПРОЦЕС ПОЧАТКОВОї ШКОЛИ}

\author{
Віра Андрієвська \\ кандидат педагогічних наук, доцент,
}

докторант кафедри початкової, дошкільної та професійної освіти

Харківський національний педагогічний університет імені Г.С. Сковороди,

м. Харків, Україна

http://orcid.org/0000-0003-1632-4045

andvera80@gmail.com

Анотація. У статті висвітлено етапи впровадження IКТ в освітній процес початкової школи: експериментальний етап; етап інтеграції навчання інформатики з навчанням базових дисциплін початкової школи; етап становлення дисципліни «Інформатика» як самостійного предмета. Розкрито особливості використання IКТ на кожному з етапів упровадження: формування в учнів комп'ютерної грамотності, становлення інформаційної культури й подальший розвиток алгоритмічної культури школярів на першому етапі; оволодіння учнями комп’ютером як засобом пізнання процесів і явищ, що відбуваються навколо на другому етапі; наскрізне застосування ІКТ у начальному процесі початкової школи на третьому етапі. Обгрунтовано необхідність переосмислення цілей, змісту, засобів, методів і форм інформатичної підготовки молодших школярів на сучасному етапі розвитку IКТ і зростанні нового покоління дітей в інформатизованому суспільстві.

Ключові слова: : етапи; IКТ; впровадження IКТ; початкова школа.

Постановка проблеми в загальному вигляді. Сьогодні процес початкової навчальної підготовки школяра й способи педагогічної роботи вчителя трансформуються. Впливовим фактором такого реформування $\epsilon$ розвиток й широке розповсюдження IКТ як в освітній сфері, так і в усіх сферах соціального життя. Поширення ІКТ змінює звичні методи представлення інформації, іiї опрацювання, усвідомлення, ініціюючи появу нових потреб сучасного молодшого покоління до отримання знань особливо під час навчального процесу. У цьому ракурсі дослідження етапів упровадження ІКТ в освітній процес початкової школи є виключно важливою задачею, рішення якої багато в чому здатне вплинути на подальше успішне використання IКТ у навчальному процесі.

Аналіз останніх досліджень і публікацій. У психолого-педагогічних дослідженнях етапність упровадження ІКТ у навчальний процес висвітлено такими науковцями, як В. Биков, В. Гриценко, М. Жалдак, В. Кухаренко, С. Макєєв, Н. Морзе, Ю. Рамський та ін. Аналіз педагогічних джерел дозволяє дійти висновку, що дослідники торкались лише окремих аспектів еволюції IКТ, а це насамперед дозволяло їм виявити лише деякі підходи стосовно періодизації впровадження IКТ в освітній процес [4]. Однак у ракурсі впровадження нового Державного стандарту початкової загальної освіти періодизація розвитку та 
впровадження ІКТ в освітній процес початкової школи потребує подальших досліджень та наукових розробок.

Формулювання цілей статті (постановка завдання). Мета статті полягає у висвітленні етапів та аналізу особливостей упровадження IКТ в освітній процес початкової школи.

Результати дослідження. Важливість розвитку, упровадження i використання IКТ у практиці початкового навчання сьогодні підтверджується різними нормативними й установчими документами. Проте зазначимо, що початкова школа в системі загальної освіти залучилась до процесу інформатизації навчального процесу останньою, що зумовлено низкою причин. По перше, упровадження комп'ютера в початкову школу гальмувалося тривалою дискусією науковців, медичних працівників щодо доцільності використання комп'ютера молодшими школярами, бо деякі дослідження (Н. Апатова, А. Платонова, Н. Полька, О. Савченко та ін.) виявили негативний вплив роботи 3 комп'ютером на учнів молодшого шкільного віку (розвиток гіподинамії, порушення зору, втрата концентрації уваги, навантаження на руки, шию тощо).

Багато дослідників (Ю. Бабаєва, І. Балонов, А. Сгоров, Н. Карвацька та ін.) звертають увагу й на психологічний аспект застосування комп'ютера дітьми молодшого віку - виникнення Інтернет-залежності дитини, іiі захоплення Інтернет-спілкуванням, комп'ютерними й онлайн-іграми i, як наслідок, істотно посилюється цікавість віртуальною реальністю. Наприкінці минулого сторіччя психологи наголошували на тому, що перевага інформаційних технологій у навчальних програмах зводить нанівець процес навчання, тому що учні молодшого віку воліють звертати увагу на ігрові елементи замість смислових, відволікаючись від рішення дидактичних задач [11].

Поглиблене психологічне дослідження впливу комп'ютерних ігор на розвиток дитини було проведено Японськими вченими (Університет Тохоку), які виявили їхній негативний вплив на дитячу психіку, адже під час комп'ютерних ігор стимулювалися лише ті частини мозку дитини, які відповідають за зір та м'язову моторику. Частина мозку, яка допомагає дитині контролювати свої негативні емоції при комп'ютерній грі взагалі не стимулюється, що призводить до розвитку найрізноманітніших форм соціальної дезадаптації й асоціальної поведінки: емоційна нестійкість, підвищена збудливість, тривога, напруженість, конфліктність й агресивність дітей, зниження здатності до навчання [3;7].

Сьогодні такі недоліки компенсуються вдосконаленням комп'ютерної техніки, розвиненістю програмних засобів, зокрема:

- використання спеціалізованих програмних засобів, за допомогою яких можна фільтрувати зміст Web-сторінок (за необмеженою кількістю умов);

- можливість обмежувати доступ учнів молодшого віку до дорослого контенту в мережі Інтернет;

- використання Web-додатків (StopKids, Time Boss PRO, NkTimeTracker від Nicekit Software, ContentWasher), які дозволяють накладати часові обмеження 
роботи дитини за комп’ютером або з конкретною програмою. Відповідно до налаштування комп'ютер автоматично припиняє роботу й блокує включення до вказаного в параметрах проміжку часу. Крім того, розвиненість сучасних програмних продуктів дозволяє, наприклад, батькам віддалено (і непомітно для дитини) задавати режим роботи комп'ютера в реальному часі, оперативно додавати або зменшувати час роботи дитини за комп'ютером;

- розробка програмних засобів відповідно до психолого-педагогічних вимог сприйняття дитиною молодшого віку інформації (спираючись на наукові дослідження, зокрема фахівців Асоціації «Комп'ютер і дитинство» щодо використання розвивальних і навчальних комп'ютерних ігор) дозволяє органічно поєднати навчальну та ігрову складову. Особливістю застосування програмного забезпечення навчального призначення $\epsilon$ неявний характер подання навчальних завдань, що забезпечує непомітне і цілком природне для молодшого школяра переростання гри в навчальну діяльність, зміну ігрових інтересів на пізнавальні, адже досягнення ігрових цілей (виграшу, призу, рекорду тощо) передбачає досягнення й певних навчальних цілей [1];

- досягненнями в галузі новітніх дисплейних технологій, що дозволяє безпечно використовувати IКТ у навчанні дітей дошкільного й молодшого шкільного віку. Принципово нова архітектура організації пікселя забезпечує чіткість багатоколірного зображення 3 високою роздільною здатністю, можливість регулювання яскравості й контрастності візуальної інформації 3 урахуванням особливостей ії сприйняття дитиною, забезпечуючи рівномірність відображення кольору при варіюванні розміру пікселя (збільшення/зменшення зображення), високу якість динаміки відеозображень, виключення мерехтіння, стійкість сучасних екранів до електромагнітних полів.

Довготривалі тенденції розвитку ІКТ, їхнє наскрізне застосування в соціумі, зростання сучасних дітей в інформатизованому оточенні не виключає й обов'язкове додержання вимог безпечної організації діяльності учнів молодшого віку $з$ ІКТ, що висвітлено в роботах М. Антропової, Н. Апатової, Н. Польки та інших.

Другою причиною певної затримки щодо застосування комп'ютера в практиці початкової освіти була відсутність комп'ютерно-орієнтованих методичних систем навчання базових дисциплін початкової школи, що передбачало розробку нового змісту навчання, нових засобів, організаційних форм і методів навчання тощо. Водночас у межах виконання проектів, прийнятих Законом України «Про Концепцію Національної програми інформатизації» (04.02.1998 року, № 75/98-ВР), Законом України «Про Національну програму інформатизації» (13.09.2001 року, № 74/98-ВР), Постановою Кабінету Міністрів України «Інформаційні та комунікаційні технології в освіті і науці на 2006 - 2010 роки» (07.12.2005 року, № 1153), Законом України «Про Основні засади розвитку інформаційного суспільства в Україні на 2007 - 2015 роки» (09.01.2007 року, № 537-V) було реалізовано належне комп’ютерне оснащення навчально- 
виховних заходів і статистичні дані на 2014 - 2015 роки показали, що рівень комп'ютеризації шкіл становить 93\% (16401 шкіл із 17604), підключення до мережі Інтернет становить 81\% (14331 шкіл) [9].

Широке впровадження IКТ в початкову школі сприяло створенню на цій основі програмних засобів навчального призначення, орієнтованих на формування інформаційної культури молодших школярів. Розроблено значну базу україномовних електронних навчально-методичних комплексів як засобу ІКТ-підтримки шкільних дисциплін, які відповідають сучасним, оновленим стандартам початкової школи. Такі електронні комплекси містять:

- навчальні прикладні програмні засоби та тестові оболонки (електронні репетитори, мультимедіа-тренажери, енциклопедії, атласи, оцінно-контролюючі програми тощо);

- предметно-орієнтовані середовища (предметно-ігрові середовища, моделюючі програми, картографічні ресурси, макро- і мікросвіти тощо);

- інтегровані навчальні засоби (електронні видання, мультимедіапрезентації, лабораторні практикуми тощо).

Сучасні прикладні програмні засоби, ІКТ-підтримка базових дисциплін початкової школи розробляються із урахуванням особливостей розвитку учнів молодшого віку й мають таку специфіку, зокрема [1]:

- інформаційна насиченість електронних ресурсів (одночасне гармонійне інтегрування різних видів інформації: високоякісної графічної, звукової, фото- і відеоінформації); засобі;

- органічне поєднання навчальної та ігрової складових у програмному

- наявність зручних засобів навігації;

- можливість працювати 3 комп'ютером у режимі діалогу інтерактивність програмних засобів;

- систему вбудованої допомоги;

- розвиток інтерфейсу «віртуальної реальності» - дозволяє працювати із новим поколінням сучасного контенту, наприклад, перегляд 3D-відео, панорамні сферичні фотографії в $360^{\circ}$;

- фіксація особистих досягнень школяра в процесі роботи тощо.

Активно поширюються в початковій навчальній практиці освітні онлайнплатформи (наприклад, Learning.ua, EdEra, Гипермаркет Знаний), які містять різні практичні матеріали: інтерактивні завдання, цікаві задачі, вправи на самоперевірку, які в привабливій (іноді ігровій) формі подають навчальний матеріал і засоби його освоєння. Програми та інтерактивні завдання розроблені згідно з оновленими стандартами Міністерства освіти і науки України, а також відповідають міжнародним освітнім стандартам Common Core, зокрема 3 математики. Крім того, такі онлайн-платформи включають шкільні онлайнпідручники, посібники, дидактичні матеріали. 
Сьогодні доступна значна кількість інструментальних педагогічних засобів, онлайн-освітніх інтерактивних хмарних сервісів, які дають змогу вчителеві підбирати навчальний матеріал, самостійно готувати практичні завдання, зручно й ефективно візуалізовувати статичну й динамічну інформацію, що відповідає змісту конкретної теми будь-якої базової дисципліни початкової школи.

Такий комплекс реалізованих заходів сприяє ефективній реалізації потужних дидактичних можливостей ІКТ у початковій школі. Концептуальні засади подальшого розвитку середньої освіти розроблені Міністерством освіти і науки України в Концепції Нової української школи (НУШ). Під час підготовки засад бралися до уваги «Концепція розвитку освіти України на період 2015 2025 років», підготовлена Стратегічною дорадчою групою «Освіта» в рамках спільного проекту Міжнародного фонду «Відродження» та БФ «Інститут розвитку освіти», а також «Концепція середньої загальноосвітньої школи України» Національної академії педагогічних наук України, «Візія нової української школи», підготовлена спільнотою відповідального вчительства EdCamp Ukraine. Основу НУШ складає наскрізне застосування IКТ в освітньому процесі й поступовий перехід від одноразових проектів до системного процесу, який охоплює всі види діяльності школяра [12].

Наступним фактором, який гальмував запровадження IКТ в початкову освіту була неготовність вчителів до використання ІКТ у предметно-професійній діяльності. На перешкоді стало те, що при впроваджені комп'ютера в навчальну практику вчителі не мали досвіду його використання в процесі навчання предметних дисциплін, були не обізнані специфікою безпечної роботи дитини 3 комп'ютером, із предметно-орієнтованими програмними засобами.

Часто вчителі не вміли застосувати комп'ютер на рівні грамотного користувача й не мали мотивації набути потрібних ІКТ-навичок. Відсутності такої мотивації частково сприяло те, що впровадження комп’ютера в практику навчання змінює роль учителя, адже в побудові уроку з використанням IКТ визначальною $\epsilon$ діяльність учнів, а головною функцією педагога стає завчасне моделювання схеми діяльності учнів із комп'ютером відповідно до змісту і мети уроку, реалізація комунікативних умов, коли вчитель своїми висловлюваннями i діями створює «проблемні ситуації», що стимулюють учнів до аналізу, усвідомлення змісту навчального матеріалу, активізують їхню пізнавальну діяльність. Крім того, в ІКТ-орієнтованому навчанні вчитель має надавати консультаційну допомогу школярам при роботі 3 програмним засобом, підтримувати комп'ютерно-орієнтоване співробітництво між учнями, забезпечувати психологічну підтримку учнів (обговорення проблем, які можуть виникати в дитини при роботі з комп'ютером; підвищення впевненість в учнів за рахунок підтвердження їхньої ІКТ-грамотності тощо) [5; 15].

Зазначимо, що до проведення уроків інформатики в початковій школі часто залучались учителі середньої або старшої школи, які краще володіли IКТ, але не мали належної психолого-педагогічної підготовки до роботи з учнями 
молодшого віку. Проте сьогодні проблема підготовки вчителів початкових класів до використання IКТ у професійній діяльності вирішена на достатньому рівні. Так, із часу експериментального впровадження комп'ютера в початкову ланку освіти для вчителів початкової школи курси підвищення кваліфікації реалізуються на державному рівні, часто за ініціативою таких відомих компаній, як Intel, Microsoft, Google. Сьогодні вчителі також мають можливість проходити зарубіжне стажування, під час якого вони ознайомлюються 3 новими концепціями, методами, інструментами щодо використання IКТ у практиці початкового навчання. Зокрема агентство 3 розвитку міжнародного співробітництва МЗС Держави Ізраїль (MASHAV) щорічно організовує міжнародні навчальні курси за різними темами, серед яких на особливу увагу заслуговують курси: «Education for Technology and the use of ICT in Education», «Education for Science and Math - STEM Framework».

Важливо наголосити, що сучасна практика підготовки майбутніх учителів початкової школи у ВНЗ передбачає ІКТ-складову, яка реалізується в навчальних курсах: «Сучасні інформаційні технології», «Методика інформатики», «Педагогічна інформатика», «Комп'ютерне моделювання», «Інструментальні педагогічні засоби» тощо, основна мета яких полягає в оволодінні студентами навичками застосування ІКТ у майбутній предметно-професійній діяльності, самостійно готувати дидактичні електронні ресурси, доцільно використовувати мультимедійні навчальні матеріали, створювати електронне педагогічне середовище початкової школи тощо. Крім того, у мережі Інтернет поширені інформаційно-освітні середовища, освітні онлайн-платформи, які дозволяють і майбутнім фахівцям, і працюючим учителям здійснювати мережну взаємодію для обміну практичним досвідом та формування загальнодоступної електронної програмно-методичної бази інформатизації початкової школи.

Так, упровадження комп’ютера в навчальний процес початкової школи можна представити як послідовність таких етапів:

1. Експериментальний етап - уведення пропедевтичного курсу 3 інформатики паралельно з процесом комп'ютеризації шкіл. Цей курс викладався як додатковий або на окремих уроках за рахунок годин варіативної складової навчального плану (у межах орієнтації на розвивальне навчання); часто це здійснювалось за ініціативою школи (при наявності відповідного оснащення комп'ютерного кабінету) або за наполяганням батьків.

2. Eman інтеграчї навчання інформатики 3 навчанням базових дисципліна початкової школи.

3. Етап становлення дисиииліни «Інформатика» як самостійного предмета початкової школи та включення його до інваріантної складової базового навчального плану (із 1 вересня 2013 року).

На першому етапі впровадження комп'ютера в навчальну практику основною метою було формування в учнів комп'ютерної грамотності, становлення інформаційної культури й подальший розвиток алгоритмічної 
культури школярів, що досить грунтовно розкрито в роботах Т. Бокучави, Ю. Горвица, Д. Зарецького, Ю. Первина, А. Труханов, С. Тур та інших.

Формування в учнів молодшого шкільного віку інформаційної культури було зорієнтовано на закладання основ раціональної й ефективної роботи 3 комп'ютером як провідним інструментом діяльності в новому інформаційному суспільстві. Педагогічні задачі, що розв'язувались на комп'ютерних заняттях, передбачали оволодіння школярами такими поняттями, як «Множина», «Символ» (як позначення об’єкта - піктограма), «Інформація», «Алгоритми», «Комп'ютерний вірус» тощо. Під час практичних занять за комп’ютером школярі опановували навички набору тексту за допомогою клавіатурних тренажерів, навички оперування мишею. Проте часто діти вивчали «світ комп'ютерів» за картинками в книжці, навчальні вправи виконувались у робочих зошитах. Також слід звернути увагу, що при підготовці методичних посібників на той час передбачалося, що учні вперше будуть опановувати первинні навички роботи за комп'ютером. Так, Ю. Первин зазначає, що другокласник, який уперше починає систематичне спілкування з комп'ютером, більше витрачає часу на пошук необхідних позицій на клавіатурі, довше думає над функціями основних управляючих клавіш тощо [6].

Необхідно зазначити, що на першому етапі впровадження комп'ютера в початкову освітню практику посилена увага приділялася формуванню понять про алгоритмічні структури, навички роботи 3 різними виконавцями (Лого, С. Пейперта) для пропедевтики навчання школярів мов програмування. Проте подальший розвиток цих ідей показав, що такий напрям не дає належних практичних результатів використання комп'ютера учнями, особливо при розв'язуванні проблем життєвого характеру.

Зростаюча актуальність доопрацювання пропедевтичного курсу інформатики в початковій школі, що пов'язана як зі стрімким поширенням $i$ розвиненістю ІКТ у різних сферах життєдіяльності, так і 3 масштабною розробкою прикладних програмних засобів, орієнтованих на молодших школярів, із вільним доступом до предметних освітніх електронних ресурсів, призвела до усвідомлення необхідності переходу від вивчення комп'ютера як об'єкта до його інтеграції в усі без винятку предмети. Дискусії щодо місця навчання інформатики в школі поступово схилили їх учасників до розуміння того, що інформаційні технології мають інтегруватися в усі без винятку предмети і стати дієвим багатофункціональним засобом навчальної діяльності учня та професійної діяльності вчителя, а також узагальненим каталізатором підвищення ефективності всього навчально-виховного процесу в початковій школі [13].

На другому етапі інформатизації початкової освіти - етапі інтеграції комп'ютера в процес навчання базових дисциплін перспективним було оволодіння учнями комп'ютером як засобом пізнання процесів і явищ, що відбуваються навколо. Ефективність застосування комп'ютера на предметних дисциплінах зумовлена низкою факторів [10]: 
- різноманітність форм представлення інформації;

- високий ступінь наочності; можливість організації ефективної колективної та індивідуальної дослідницької роботи 3 використанням комп'ютера;

- можливість диференціювати роботу учнів залежно від рівня підготовки, пізнавальних інтересів тощо, використовуючи сучасні ІКТ;

- можливість організувати автоматизований оперативний контроль рівня засвоєння знань і своєчасну допомогу з боку вчителя тощо.

Використання комп'ютера в процесі вивчення базових предметів відкрило цілий ряд можливостей для різнобічного, нетрадиційного, наочного осмислення учнями предметного матеріалу, на що вказували такі науковці, як Л. Білоусова, Т. Запорожченко, Л. Кравченко, О. Локшина, Н. Олефіренко, Н. Рудницька, М. Синиця, С. Шумигай та інші. Застосування комп'ютера на уроках надало можливості активізувати пізнавальні інтереси учнів під час вивчення та закріплення нового матеріалу, підвищити мотивацію навчальної діяльності, організувати продуктивну самостійну роботу школярів [8].

Перехід до другого етапу інформатизації початкової ланки освіти дозволив реалізувати такі педагогічні завдання, як:

- інтенсифікація всіх рівнів навчально-виховного процесу, підвищення його ефективності та якості;

- запровадження особистісно орієнтованої моделі навчання;

- підвищення наочності викладу навчального матеріалу;

- розширення спектра практичних задач із дисциплін;

- привнесення ігрової компоненти в загальну структуру навчання базових дисциплін учнів молодшого шкільного віку;

- ефективна організація колективної й групової роботи під час виконання спільних проектів учнями різної вікової категорії;

- надання можливості організовувати дослідну діяльність учнів молодшого шкільного віку;

- автоматизація контролю навчальних досягнень.

На основі узагальнення вітчизняного та зарубіжного досвіду інформатизації освіти згодом виникла нагальна потреба в розробці концепції подальшого розвитку й спрямування загальноосвітнього курсу інформатики, що продиктовано рядом причин [2]:

1) інтенсивність процесу становлення інформатизованого суспільства зумовлює нові вимоги до цілей та змісту освіти;

2) розвиток інформаційно-комунікативного середовища суспільства призводить до того, що новітні технології стають дієвою складовою інформаційно-комунікаційних зв'язків без обмежень. 3'явилась нова форма комунікації; 
3) поширення нової форми комунікації сприяє зростанню значущості формування в нового покоління емоціонального інтелекту (EQ - Emotional Iintelligence);

4) інформаційно-технологічний розвиток об’єктивно впливає на умови розвитку і становлення молодого покоління в сучасному світі, що зумовлює необхідність формування в дітей цифрового інтелекту (DQ -Digital Intelligence Quotient);

5) інформаційно-технологічний розвиток об'єктивно зумовив трансформацію традиційних видів діяльності (наприклад, перехід комунікативних стосунків у віртуальний простір);

6) зниження вікового бар'єру використання дітьми IКТ - упровадження та поширення IКТ у дошкільній освіті.

Отже, перехід до наступного етапу інформатизації початкової ланки освіти - етапу становлення дисципліни «Інформатика» як самостійного предмета початкової школи - $є$ логічним продовженням пошуку глибинного сенсу трансформації сучасної початкової школи.

На третьому етапі інформатизації початкової освіти - етапі становлення дисципліни «Інформатика» як самостійного предмета початкової школи та включення його до інваріантної складової базового навчального плану перспективним стало наскрізне застосування IKT у начальному процесі. Запровадження IКТ в освітній галузі переходить від одноразових проектів у системний процес, який охоплює всі види діяльності школяра і спрямований на набуття учнями вмінь доцільно використовувати сучасні високотехнологічні інструменти як у процесі навчально-пізнавальної діяльності, так і успішно застосовувати стосовно реальних об’єктів діяльності [12].

Так, наприклад, загальні цілі математичної освітньої галузі відображають інноваційну концепцію нового Державного стандарту початкової школи й передбачають, зокрема, використання IКТ на уроках математики 3 метою розв'язання учнями проблемних або нестандартних завдань, роботу школярів із різними джерелами інформації.

Через систему практико-орієнтованих завдань у межах технологічної освітньої галузі школярі досліджують комп'ютерні моделі реально наявних об'єктів/предметів (літак, судно та інше); навчаються конструювати або створювати комп'ютерні образи, графічні композиції (користуючись геометричними шаблонами, багатоколірною комп'ютерною палітрою, бібліотекою електронних зображень тощо); експериментують, створюючи нові моделі/об'єкти з бази наявних елементів (складні механізми, казкові тварини, футуристичні ландшафти тощо), реалізуючи таким чином власні творчі задуми. У межах іншомовної освітньої галузі в новому Стандарті початкової освіти передбачено організацію соціальної онлайн-взаємодії школярів тощо [12].

Висновки $з$ дослідження і перспективи подальших розвідок у цьому напрямі. Так, перехід до третього етапу інформатизації початкової освіти вимагає кардинального переосмислення цілей, змісту, засобів, методів і форм 
підготовки з інформатики молодших школярів на сучасному етапі розвитку IКТ і зростанні нового покоління дітей в інформатизованому суспільстві, адже інформатика сьогодні не лише окрема дисципліна, це й динамічне середовище навчання інших предметів, і вже звичний засіб реалізації різноманітних потреб дитини в реальних життєвих ситуаціях.

\section{СПИСОК ВИКОРИСТАНИХ ДЖЕРЕЛ}

1. Андрієвська, В. М. і Олефіренко, Н. В. (2011). Інформаційні технології у початковій школі. Харків, Україна: ХНПУ.

2. Андрієвська, В. М. (б.д.). Трансформачія початкової школи в умовах інформатизації освіти.

Взято

http://www.rusnauka.com/22_SEN_2017/Pedagogica/4_228294.doc.htm

3. Влияние компьютерных игр на психику ребенка. (б.д.). Взято 3 http://www.microarticles.ru/article/vlijanie-kompjuternih-igr-na-psihiky-rebenka.html

4. Воронкін, О. (2014). Періодизація розвитку інформаційно-комунікаційних технологій навчання. Вища освіта Украӥни, 3, 109-116.

5. Гончаренко, Л. М. і Костенко, О. І. (б.д). Використання ІКТ для підвищення якості навчання. Освіта.UA. Методика та технологія. Взято 3 http://osvita.ua/school/lessons_summary/edu_technology/27861/

6. Зарецкий, Д. В., Зарецкая, 3. А. і Горвиц, Ю. М. (1995). Информационная культура: Модуль: Класс 1. Москва, Россия: Дрофа.

7. Козидубова, С. М. (1999). Особенности эмоциональных нарушений при неврозах у подростков. Таврический журнал психиатрии, 3 (10). Взято с https://www.kazedu.kz/referat/98417

8. Кравченко, Л. І. (2004). Персональний комп’ютер на уроці математики як засіб активації пізнавальної діяльності учнів. Математика в школах України, 2, 8-11.
9. Національна
рада
реформ.
(б.д.).
Взято

3 http://reforms.in.ua/ua/reform/indicator/11076

10. Петрікова, Н. І. (б.д.). Упровадження інформаційно-комп'ютерних технологій у навчально-виховний процесс. Освіта.UA. Методика ma технологія. Взято 3 http://osvita.ua/school/lessons_summary/edu_technology/33682/

11. Подкорытов, В. С. (1998). Новые технологии в медико-социальной реабилитации детей и подростков с органическими поражениями нервной системы, страдающих речевыми и психическими расстройствами. Материаль Национальной конференщии психологов и логопедов. (С. 66-68). Харьков, Украина.

12. Проект нового державного стандарту початкової загальної освіти. (б.д.). Взято 3 http://newstandard.nus.org.ua/

13. Суховірський, О.В.(2005). Підготовка майбутнього вчителя початкової иколи до використання інформаційних технологій. (Дис. канд. пед. наук). Київ, Україна: Інститут педагогіки АПН України.

14. Щодо методичних рекомендацій для експериментальних загальноосвітніх $\begin{array}{lllllll}\text { навчальних закладів. № } 1 / 9-450 . & \text { (2017, } 23 & \text { серпня). Взято } 3\end{array}$ http://osvita.ua//legislation/Ser_osv/57230/

15. UNESCO Institute for Information Technologies in Education. (n.d.). Retrieved from http://iite.unesco.org/pics/publications/ru/files/3214728.pdf;\%20\%D0\%A1.243-244

\section{ЭТАПЫ ВНЕДРЕНИЯ ИКТ В ОБРАЗОВАТЕЛЬНЫЙ ПРОЦЕСС НАЧАЛЬНОЙ ШКОЛЫ}




\title{
Вера Андриевская
}

кандидат педагогических наук, доцент, докторант кафедры начального, дошкольного и профессионального образования Харьковский национальный педагогический университет

имени Г. С. Сковороды, г. Харьков, Украина

http://orcid.org/0000-0003-1632-4045

andvera80@gmail.com

Аннотация. В статье освещены этапы внедрения ИКТ в образовательный процесс начальной школы: экспериментальный этап; этап интеграции обучения информатике с обучением базовых дисциплин начальной школы; этап становления дисциплины «Информатика» как самостоятельного предмета. Раскрыты особенности использования ИКТ на каждом из этапов внедрения: формирование у учащихся компьютерной грамотности, становление информационной культуры и дальнейшее развитие алгоритмической культуры школьников на первом этапе; овладение учащимися компьютером как средством познания процессов и явлений, происходящих вокруг на втором этапе; сквозное применение ИКТ в учебном процессе начальной школы на третьем этапе. Обоснована необходимость переосмысления целей, содержания, средств, методов и форм подготовки младших школьников на современном этапе развития ИКТ и взросления нового поколения детей в информатизированном обществе.

Ключевые слова: этапы; ИКТ; внедрение ИКТ; начальная школа.

\section{STAGES OF IMPLEMENTING ICT IN EDUCATIONAL PROCESS IN PRIMARY SCHOOLS}

\author{
Vira Andriievska \\ Candidate of Pedagogical Sciences, Ph.D., Associate Professor
}

Doctorate in the Department of Primary, Pre-school and Vocational Education

H.S. Skovoroda Kharkiv National Pedagogical University

Kharkiv, Ukraine

http://orcid.org/0000-0003-1632-4045

andvera80@gmail.com

Abstract. The article focuses on the relevant problem of studying the stages of implementing ICT in educational processes in primary schools. The analysis of publications showed that the stages of ICT implementation in the educational process had been studied by such scientists V. Bykov, M. Zhaldak, O. Mayboroda, N. Morse and others. This study aims to analyze the stages of implementing ICT in educational process in primary schools. The results of this study has shown that the primary school is integrated into the process of informatization of education. This situation has been caused by a variety of reasons, particularly by the long discussion of scholars and medical staff regarding the feasibility of using ICT by junior pupils. The second reason is lack of computer-oriented methodological teaching systems for primary school disciplines. The next factor that impedes the introduction of ICT into primary education is the lack of teachers' readiness to use ICT in their subject-professional activities. Thus, the introduction of computerization of the primary education can be represented as a sequence of the following steps: experimental stage -introduction of a training course in computer studies simultaneously with the computerization process of education; the stage of integration of computer studies curriculum with the basic disciplines of primary school; stage of designing the subject 'Computer Studies' as a separate element of primary school education and its inclusion in the invariant component of the basic curriculum. The transition to the third stage of 
informatization of primary education requires a radical rethinking of junior pupils' computer studies training at the current stage of development of ICT and the shift of a new generation of children to a computerized society, because today's computer science is not only a separate discipline, but also a dynamic training environment of other subjects, and is already the usual means of realization of various needs of the child in real life situations.

Key words: stages; ICT; ICT implementation; primary school.

\section{REFERENCES}

1. Andriievska, V. M., \& Olefirenko, N. V. (2011). Information technologies in elementary school. Kharkiv, Ukraine: KhNPU.

2. Andriievska, V. M. (n.d.). Transformation of elementary school in the conditions of informatization of education. Retrieved from http://www.rusnauka.com/22_SEN_2017/Pedagogica/4_228294.doc.htm

3. Influence of computer games on the psyche of the child. (n.d.). Retrieved from http://www.microarticles.ru/article/vlijanie-kompjuternih-igr-na-psihiky-rebenka.html

4. Voronkin, O. (2014). Periodization of development of information and communication technologies of teaching. Vyshcha osvita Ukrainy, 3, 109-116.

5. Honcharenko, L. M., \& Kostenko, O. I. (n.d.). Using ICT for improving the quality of education. Osvita.UA. Metodyka ta tekhnolohiia. Retrieved from http://osvita.ua/school/lessons_summary/edu_technology/27861/

6. Zareckij, D. V., Zareckaja, Z. A., \& Gorvic, Ju M. (1995). Information culture: Module: Class 1. Moscow, Russia: Drofa.

7. Kozidubova, S. M. (1999). Features of emotional disturbances in neurosis in adolescents. Tavricheskij zhurnal psihiatrii,3 (10). Retrieved from https://www.kazedu.kz/referat/98417

8. Kravchenko, L. I. (2004). Personal computer in the lesson of mathematics as a means of activating cognitive activity of students. Matematyka $v$ shkolakh Ukrainy, 2, 8-11.

9. National Council for Reforms. (n.d.). Retrieved from http://reforms.in.ua/ua/reform/indicator/11076

10. Petrikova, N. I. (n.d.). Implementation of information and computer technologies in the educational process. Osvita.UA. Metodyka ta tekhnolohiia. Retrieved from http://osvita.ua/school/lessons_summary/edu_technology/33682/

11. Podkorytov, B. C. (1998). New technologies in the medical and social rehabilitation of children and adolescents with organic lesions of the nervous system suffering from speech and mental disorders. Proceedings from National Conference of Psychologists and Speech Therapists. (C. 66-68). Kharkiv, Ukraine.

12. Draft new state standard for elementary general education. (n.d.). Retrieved from http://newstandard.nus.org.ua/

13. Sukhovirskyi, O. V. (2005). Preparation of the future teacher of elementary school to the use of information technologies. (PhD dissertation). Kyiv, Ukraine: Instytut pedahohiky APN Ukrainy.

14. On methodological recommendations for experimental secondary schools. № 1/9-450. (2017, August 23). Retrieved from http://osvita.ua/legislation/Ser_osv/57230/

15. UNESCO Institute for Information Technologies in Education. (n.d.). Retrieved from http://iite.unesco.org/pics/publications/ru/files/3214728.pdf;\%20\%D0\%A1.243-244

Матеріали надійшли до редакції 13.05.2018 р. 